Corresponding Author:

Farhad Gilavand;

email:

farhadgilavand@yahoo.com

Production and Hosting by

Knowledge E

(ㄷ) Farhad Gilavand et al. This article is distributed under the terms of the Creative

Commons Attribution License,

which permits unrestricted use and redistribution provided that the origina author and source are credited.

Editor-in-Chief: Dr. Alireza Rafiei

\section{L-Asparaginase-producing Rouxiella Species Isolation, Antilleukemia Activity Evaluation, and Enzyme Production Optimization}

\author{
Farhad Gilavand ${ }^{1}$, Abdolrazagh Marzban², and Amirarsalan Kavyanifard ${ }^{3}$ \\ ${ }^{1}$ Department of Microbiology, Islamic Azad University, Khorramabad Branch, Khorramabad, Iran \\ ${ }^{2}$ Razi Herbal Medicines Research Center, Lorestan University of Medical Sciences \\ ${ }^{3}$ Payame Noor University, Department of Biology, Tehran, Iran
}

\section{Abstract}

Background: L-Asparaginase (L-Asp) is used as an efficient anti-cancer drug, especially for acute lymphoblastic leukemia (ALL). Currently, two bacterial asparaginase isoenzymes are used for cancer treatment.

Therefore, this research focused on isolating native bacteria with the ability to produce L-Asp.

Materials and Methods: L-Asp producing bacteria were isolated from soil samples on 9K medium supplemented with L-Asp as nitrogen source. Detection of L-Asp activity was performed by observing color change of the agar medium from yellow to orange due to the release of ammonia around the colonies. After the isolation and identification of the bacterium, L-Asp production was first optimized by the one factor-at-the-time (OFAT) technique followed by the response surface method. Next, the enzyme was extracted, purified, and assessed for antileukemia activity on U937 and MRC-5 cell lines.

Results: The results revealed that L-Asp produced by Rouxiella sp. AF1 significantly inhibited the growth of $U 937$ cells at a dose of up to $0.04 \mathrm{IU} / \mathrm{ml}$, while MRC- 5 was not affected at any enzyme doses. The final purification of the enzyme was achieved by column chromatography (Sephadex G-100) at approximately $0.31 \mathrm{mg} / \mathrm{ml}$, and its specific activity was determined to be $0.51 \mathrm{lU} / \mathrm{mg}$. The OFAT optimization experiments were performed primarily to determine optimal enzyme conditions, which were found to be neutral $\mathrm{pH}(\mathrm{pH} 7), 30{ }^{\circ} \mathrm{C}$ temperature, and $3 \% \mathrm{NaCl}, 1 \%$ peptone, and $1 \%$ glucose concentrations. Statistical optimization was based on five factors obtained from OFAT, and response surface method (RSM) analysis introduced a quadratic model for enzyme production at the optimal range of these variables. This model provided an equation for measuring the effect of physiochemical conditions on final enzyme production.

Conclusion: We showed that native bacteria may be novel candidates for isolating new metabolites such as L-Asp. Because many bacteria grow in unknown environments with unique ecological properties, the probability of discovering novel bacterial species producing bioactive compounds is high.

Keywords: Antileukemia activity, L- Asparaginase, Response Surface Method, Rouxiella sp. AF1, 


\section{Introduction}

L-Asp is an amidase enzyme that is involved in the hydrolysis of L- asparagine (Asn) into aspartic acid and ammonia. As this enzyme suppresses Asn metabolism, it possesses antitumor effects [1].

In addition to the versatile applications of L-Asp, this enzyme is also an effective antitumor agent for the treatment of acute lymphoblastic leukemia (ALL) [2]. Lymphoblastic leukemia cells are unable to synthesize adequate amounts of Asn, and they depend upon the serum levels of Asn for their survival and growth. L-Asp catalyzes the hydrolysis of Asn, resulting in depletion of serum Asn and subsequent Asn deficiency in leukemic cells, ultimately leading to cell death [3].

L-Asp can be obtained from several sources, including animals, plants, and microorganisms. Microbial L-Asp, however, possesses many advantages compared to that derived from other sources. Microbial enzymes are preferred for industrial purposes due to their high catalytic activity, stability, and ease of production and optimization compared to those of plant and animal enzymes [4]

Numerous bacterial species have been found to produce L-Asp; however, only L-Asp produced by Escherichia coli and Erwinia carotovora has been approved for use as an antitumor drug [5].

Although L-Asp derived from Escherichia coli and Erwinia carotovora is currently used for medical applications, this enzyme does possess several limitations such as high immunogenicity. Therefore, it may be medically beneficial to identify newly isolated strains that produce more efficient L-Asp for cancer treatment. L-Asp derived from novel locally isolated strains may overcome the current limitations [6].

The aim of our research was to isolate bacterial strains producing L-Asp from agricultural soils located near Doroud City in Lorestan, Iran, and to then purify the L-Asp derived from these strains to characterize and assay its antitumor activity. L-Asp production by these bacteria was maximally optimized by utilizing the response surface method.

\section{Materials and Methods}

\subsection{Media and chemicals}

Phenol red was purchased from Sigma, agar was purchased from Merck, and all other materials were laboratory grade as received. The M9 medium used for L-Asp production contained (for $100 \mathrm{ml}$ ) glucose $(1 \mathrm{~g}), \mathrm{K}_{2} \mathrm{HPO}_{4}(0.05 \mathrm{~g}), \mathrm{CaCl}_{2} .2 \mathrm{H}_{2} \mathrm{O}(0.001 \mathrm{~g}), \mathrm{FeSO}_{4} \cdot 7 \mathrm{H}_{2} \mathrm{O}$ 
$(0.001 \mathrm{~g})$, and L-Asparagine $(0.1 \mathrm{~g}) . \mathrm{M} 9$ agar was prepared by adding $1.5 \mathrm{~g}$ of agar to $\mathrm{M} 9$ basal ingredients.

\subsection{Bacterial isolation for Asparaginase activity}

Bacterial colonies were primarily isolated from agricultural soil samples collected from farmlands surrounding Doroud City in Lorestan, Iran. To isolate these colonies, the soil samples were initially suspended into $100 \mathrm{ml}$ distilled water, and then $1 \mathrm{ml}$ of the suspension was serially diluted to $10^{-3}$. One hundred microliters of each dilution were spread onto Muller Hinton agar plates (MHA) and incubated at $37^{\circ} \mathrm{C}$ for $48 \mathrm{~h}$. Isolation of asparaginase-producing bacteria was conducted on M9 agar plates using the spot cultivation method on colonies isolated in the previous step. After a $48 \mathrm{~h}$ incubation, colonies that produced extracellular L-Asp were selected based on the presence of a red colored halo resulting from the production of ammonia within the yellow background of the agar medium.

\subsection{Identification of asparaginase-producing bacteria}

Selected bacteria were cultivated in M9 Broth and incubated at $37^{\circ} \mathrm{C}$ for $48 \mathrm{~h}$. Genomic DNA was extracted from bacterial cells using a DNA extraction kit. The bacteria were examined based on biochemical properties and cell morphology according to Bergey's Manual of Determinative Bacteriology [7]. Phylogenetic identification of the bacteria was performed using genomic sequencing of the 16S rDNA gene fragment for further confirmation of biochemical results. After genomic DNA extraction, 16S rDNA fragments were amplified by PCR using one set of primers that included Fd1 (5-AGAGTTTGATCCTGGC TCAG-3) and Rd1 (5-AGGAGGTGATCCAGCC-3). The PCR reaction materials contained a master mix and a loading dye from Wizol Co. South Korea. The DNA amplification program consisted of an initial denaturation at $94^{\circ} \mathrm{C}$ for $5 \mathrm{~min}, 30$ cycles of denaturation at $95{ }^{\circ} \mathrm{C}$ for $1 \mathrm{~min}$, annealing at $55^{\circ} \mathrm{C}$ for $45 \mathrm{~s}$, extension at $72{ }^{\circ} \mathrm{C}$ for $1 \mathrm{~min}$, and a final extension at $72{ }^{\circ} \mathrm{C}$ for $7 \mathrm{~min}$ [8]. After the amplification process, the PCR product was separated on a $1 \%$ agarose gel and visualized by staining with safe stain (Sinaclon Co., Iran) under a UV transilluminator. The purified 16S rDNA PCR product was sequenced by Sinagene Company (Tehran, Iran), and the nucleotide sequences including forward and reverse sequences were edited by BioEdit software version 5.0.6 (Abbott company, Calsbad, CA, USA) and analyzed using BLAST web-based software in NCBI Genbank 
(http://blast. ncbi.nlm.nih.gov/BLAST.cgi). After identification of each bacterium, the 16S rDNA fragment sequences were submitted to NCBI for accessioning.

\subsection{L-ASP assay in broth medium}

L-Asp activity was assayed in M9 broth medium at a volume of $100 \mathrm{ml}$ in $250 \mathrm{ml}$ flasks. Briefly, $1 \mathrm{ml}$ of bacterial cell suspension was inoculated in $100 \mathrm{ml}$ sterile $\mathrm{M} 9$ medium and incubated at $35^{\circ} \mathrm{C}$ for $24 \mathrm{~h}$. The produced enzyme was extracted by centrifugation of the culture medium at $8,000 \mathrm{rpm}$ for $15 \mathrm{~min}$. Then, the cell-free supernatant (CFS) was used for L-Asp assays. L-Asp activity was determined based on the amount of ammonia formed from hydrolysis of Asn according to the Nessler method. Briefly, $1 \mathrm{ml}$ of the cell free supernatant containing the crude enzyme was added to $2.0 \mathrm{ml}$ of sodium borate buffer $(0.1 \mathrm{M}, \mathrm{pH} 8.5)$ in glass tubes. Next, $1 \mathrm{ml}$ of L-Asn solution $(0.05 \mathrm{M})$ was added to the reaction tubes. The tube samples were then incubated at $37^{\circ} \mathrm{C}$ for $15 \mathrm{~min}$. The enzyme reaction was then halted by the addition of $0.5 \mathrm{ml}$ of trichloroacetic acid (TCA, $15 \%)$. The tubes were centrifuged at $12,000 \mathrm{rpm}$ for $15 \mathrm{~min}$ to precipitate the inactivated enzyme. Finally, the released ammonia was assayed using the Nessler method.

\subsection{Enzyme extraction and purification}

The M9 culture medium was centrifuged at $6,000 \mathrm{~g}$ for $15 \mathrm{~min}$ at $4{ }^{\circ} \mathrm{C}$ to precipitate the bacterial cells. The CFS containing the crude enzyme was saved for purification steps. An equal volume of the CFS was mixed with $70 \% \mathrm{w} / \mathrm{v}$ glacial ammonium sulfate solution and then stored on ice for $20 \mathrm{~min}$. The mixture was then centrifuged at 4,000 $\mathrm{g}$ at $4{ }^{\circ} \mathrm{C}$ for $15 \mathrm{~min}$. The precipitate was dissolved in phosphate buffer (PBS) $(0.1 \mathrm{M}, \mathrm{pH}$ 7) and subjected to dialysis against an extensive volume of PBS (0.01 M). To purify the enzyme, gel filtration chromatography incorporating a Sephadex G-100 column (1.25x $920 \mathrm{~cm}$ ) was performed as described in a previous study. Briefly, $10 \mathrm{ml}$ of the dialysis products were loaded onto the column and eluted with Tris- $\mathrm{HCl}$ buffer $(0.1 \mathrm{M}, \mathrm{pH}$ 8) until 25 fractions of $2 \mathrm{ml}$ were collected with collections every $10 \mathrm{~min}$. Subsequently, the obtained fractions were analyzed for asparaginase activity and protein content. Total protein content extracted in each purification step was measured using the Bradford method, and the standard curve was constructed using bovine serum albumin (BSA) [9]. 


\subsection{Antileukemia activity assay}

The antileukemia activity of purified L-Asp enzyme was investigated in the context of U937 (leukemia cell line) and MRC-5 (normal lung cell) cell lines by MTT assay method [10]. Briefly, $1.5 \times 10^{4}$ confluent cells were seeded into 96-well-plates containing $200 \mu$ RPMI-1640 medium supplemented with 10\% fetal bovine serum (FBS). Treatments were conducted using various concentrations of L-Asp. The plates were incubated at $37^{\circ} \mathrm{C}$ in a $\mathrm{CO}_{2}$ incubator for $48 \mathrm{~h}$. After incubation, $10 \mu$ of MTT reagent was added to each well, and the plates were incubated for $4 \mathrm{~h}$ under the same conditions. The formazan blue crystals formed by viable cells were precipitated by centrifugation at $1600 \mathrm{rpm}$. The supernatant was discarded, and the crystals were dissolved in $150 \mu$ l of DMSO. Absorbance of the color produced by formazan was measured at $570 \mathrm{~nm}$ using an ELISA reader. The viability of the treated sample was calculated using the following formula:

$$
\text { Viability }(\%)=\frac{\text { Treated sample absorbance }}{\text { Control sample absorbance }} \times 100
$$

\subsection{Determination of the variables required for effective asparagi- nase production}

A preliminary study was conducted using one factor at a time method (OFAT) screening, and the most effective factors that did not exhibit interaction effects on L-Asp production we determined. These factors included incubation time, temperature, $\mathrm{pH}$, and salinity, and nitrogen and carbon sources were also examined. All experiments were conducted in triplicate.

\subsection{Optimization of asparaginase production}

The screened variables that exerted the greatest effects on bacterial L-Asp production were selected for statistical optimization based on the response surface method with a central composite design (CCD). For this purpose, the significant parameters applied included $\mathrm{pH}$, temperature, peptone (nitrogen source), glucose (carbon source), and sodium chloride.

These variables were studied in an attempt to determine optimal conditions suitable for maximum L-Asp production. RSM was therefore designed to incorporate 50 full factorial CCD runs using Design-Expert software (DOE) version 7. 
The predicted values were calculated based on the level of variables using a secondorder equation as follows:

$$
Y=\beta_{0}+\sum_{i} \beta_{i} x_{i}+\sum_{i i} \beta_{i i} x_{i}^{2}+\sum_{i j} \beta_{i j} x_{i} x_{j}
$$

where $\mathrm{Y}$ introduces the predicted response around variable levels of $\mathrm{X}_{i}$ and $\mathrm{X}_{j}$. Other terms including $\beta_{0}, \beta_{i}, \beta_{i i}$, and $\beta_{i j}$ represent the regression coefficients for intercept, linear, squared, and interaction effects, respectively.

\section{Statistics}

To selection of most effective factors on L-asp production using OFAT experiments, a one-tailed analysis of variance (ANOVA) was used. For polynomial optimization, an experimental design model was created using response surface method based on central composite design algorithm.

\section{Results}

\subsection{Identification of asparaginase producing bacterium}

Of the eight bacterial species exhibiting the highest L-Asp activity, one species was selected for the next study. Initially, the isolated bacterium was identified through biochemical tests and molecular phylogenetic studies including $16 \mathrm{~S}$ rRNA analysis. The biochemical test results indicated that the bacterium belonged to the Enterobacteriaceae family. Molecular phylogenetic analysis confirmed the biochemical results as indicated in Fig 1. This figure demonstrates relationship value between the bacterium and related Enterobacteriaceae. Therefore, based on these results, the bacterium was named Rouxiella sp. AF1 and its 16S rRNA sequence were both deposited under accession number KX444200.1.

\subsection{Enzyme extraction and purification}

L-Asp obtained from Rouxiella sp. AF1 was purified by ammonium sulfate precipitation, dialysis, and gel filtration chromatography on a Sephadex G-100 column. The crude enzyme exhibited a specific asparaginase activity of approximately $0.14 \mathrm{lU} / \mathrm{mg}$, and after precipitation by ammonium sulfate the activity reached $0.27 \mathrm{IU} / \mathrm{mg}$. Next, a specific activity of $0.68 \mathrm{IU} / \mathrm{mg}$ was obtained by dialysis. The final step of L-Asp purification, which 


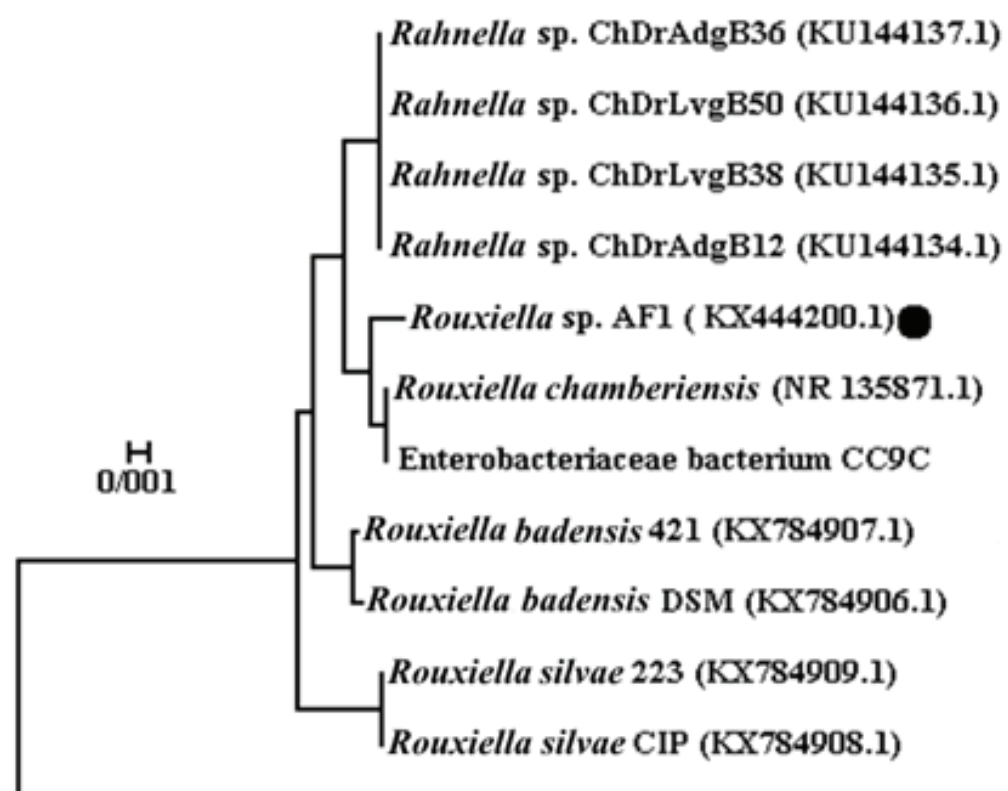

Klebsiella pneumoniae (X87276.1)

Figure 1: Phylogenetic tree indicates neighboring relations between Rouxiella sp. AF1 with retrieved 16S rRNA sequences from NCBI (BLASTn). The bacterium was labeled with a black circle. Bootstrapping was generated from 1000 replicates, and these are shown as branch distance from the nodes.

was performed using column chromatography, yielded $0.31 \mathrm{mg} / \mathrm{ml}$ of purified enzyme with a specific activity of $0.51 \mathrm{lU} / \mathrm{mg}$. The purification steps and L-Asp activity for each fraction are presented in Table 1.

TABLE 1: Purification steps of L-Asp from M9 broth medium and yield of each step and method.

Step
Crude extract
Ammonium sulfate
precipitation
Dialysis
Chromatography

\begin{tabular}{|c|}
\hline Volume (ml) \\
\hline 100 \\
\hline 42 \\
\hline 4.7 \\
\hline 1.4 \\
\hline
\end{tabular}

\begin{tabular}{c}
$\begin{array}{c}\text { Total protein } \\
\text { (mg/ml) }\end{array}$ \\
0.49 \\
0.57 \\
\hline 0.45 \\
0.31 \\
\hline
\end{tabular}

\begin{tabular}{|c|c|}
\hline Activity (IU/ml) & $\begin{array}{c}\text { Specific activity } \\
\text { (IU/mg) }\end{array}$ \\
\hline 0.048 & 0.14 \\
\hline 0.41 & 0.27 \\
\hline 0.38 & 0.68 \\
\hline 0.22 & 0.51 \\
\hline
\end{tabular}

\subsection{Purification assay of L-Asp enzyme}

To confirm L-Asp enzyme purity, the resultant obtained from column chromatography was subjected to electrophoresis on SDS-Polyacrylamide (1\%). As indicated in Fig 2, the molecular weight of the enzyme was estimated at approximately $125 \mathrm{kDa}$. Additionally, the presence of a single bond as indicated by gel electrophoresis is a well-established indicator that the enzyme possesses high purity. 


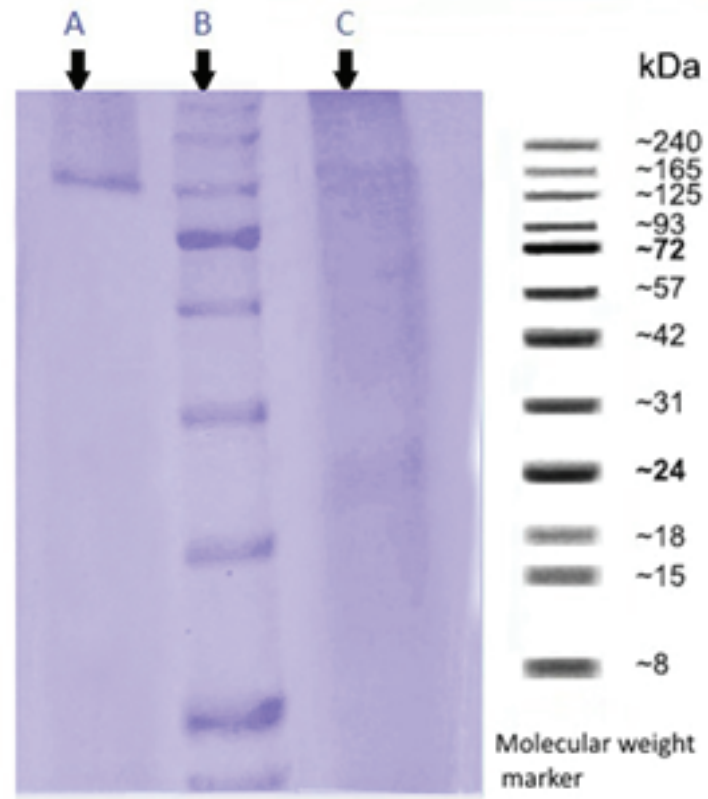

Figure 2: SDS-PAGE of purified L-Asp. Lane A shows G-100 purified L-Asp enzyme, and Lane B is protein Marker, and Lane $C$ is the negative control without sample protein (PBS buffer only).

\subsection{Antileukemia activity assay}

To investigate the antitumor activity of L-ASP derived from Rouxiella sp. AF1, we tested this enzyme in the context of human myeloid leukemia using the U937 cell line. Treatment with the purified L-ASP significantly decreased cell viability to $45 \%$ at the highest concentration, which was equal to $0.1 \mathrm{IU} / \mathrm{ml}$ (Fig. 3).

\subsection{Screening of the significant variables by OFAT experiment}

The OFAT experiments were conducted to determine optimal conditions for L-ASP production. As seen in Fig. 4, five factors including $\mathrm{pH}$, temperature, salt concentration, nitrogen, and carbon sources were determined at optimal levels to be neutral $\mathrm{pH}(\mathrm{pH})$, a temperature of $30{ }^{\circ} \mathrm{C}$, and $3 \% \mathrm{NaCl}, 1 \%$ peptone, and $1 \%$ glucose concentrations. The experimental design was established based on these factors using the response surface method. Table 1 indicates experiments suggested by the software at the central composite design calculation.

TABLE 2: Design of experiments for optimization of L-ASP production using RSM based on CCD.

$\begin{array}{cccccccc}\text { Run } \begin{array}{c}\text { Temperature } \\ \left({ }^{\circ} \mathrm{C}\right)\end{array} & \mathrm{pH} & \text { Glucose }(\mathrm{g} / \mathrm{l}) & \text { Peptone }(\mathrm{g} / \mathrm{l}) & \mathrm{NaCl}(\%) & \begin{array}{c}\text { Experimental } \\ \text { response } \\ \text { (lu/ml) }\end{array} & \begin{array}{c}\text { Predicted } \\ \text { response } \\ (\mathrm{lu} / \mathrm{ml})\end{array} \\ 1 & 30.00 & 7.00 & 1.50 & 1.50 & 3.50 & 0.038 & 0.042\end{array}$




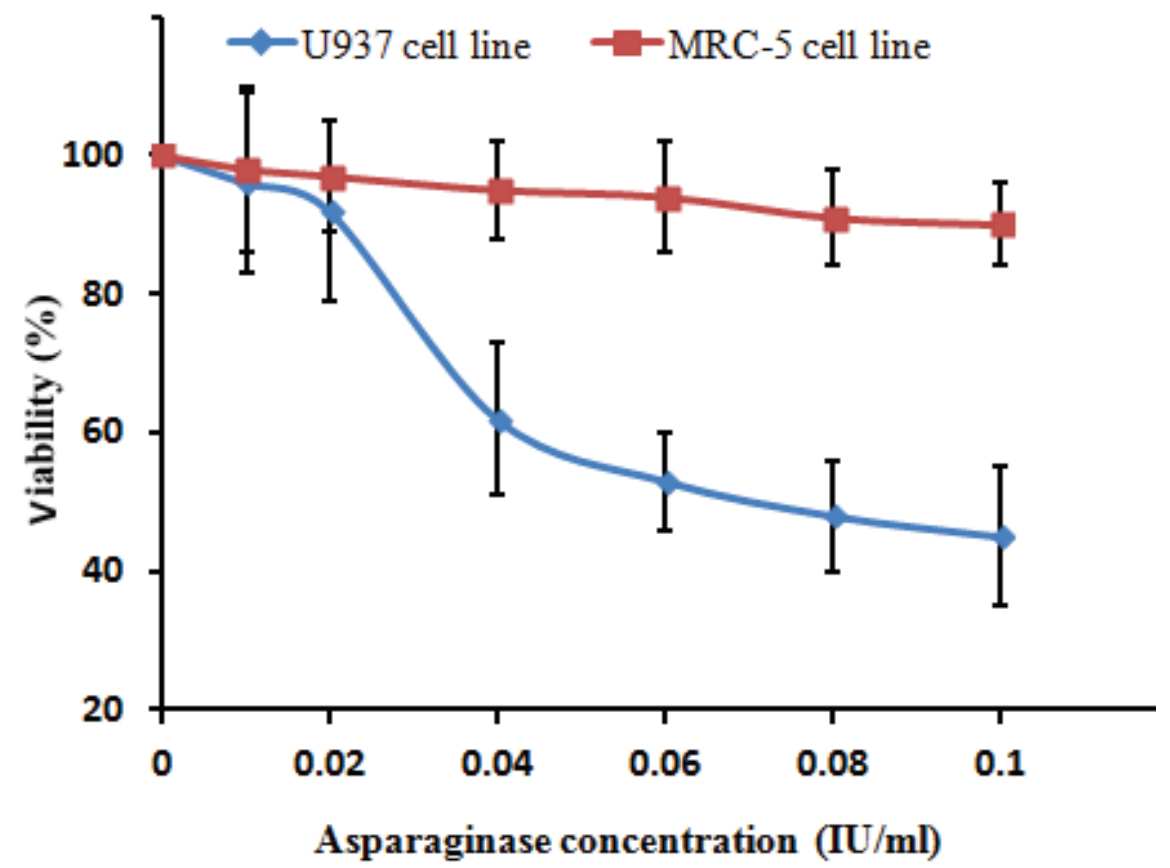

Figure 3: Dose-dependent effect of purified L-Asp from Rouxiella sp. AF1 on the viability of U937 and MRC-5 cell lines. MTT assay shows the anti-proliferative effect of L-Asp on U937 cells. After $48 \mathrm{~h}$, the treated cells were analyzed by the MTT assay, and viable cells were determined as percent of total cells compared to the control (untreated) and normal cell line (MRC-5).

\begin{tabular}{|c|c|c|c|c|c|c|c|}
\hline Run & $\begin{array}{c}\text { Temperature } \\
\left({ }^{\circ} \mathrm{C}\right)\end{array}$ & $\mathrm{pH}$ & Glucose (g/l) & Peptone (g/l) & $\mathrm{NaCl}(\%)$ & $\begin{array}{l}\text { Experimental } \\
\text { response } \\
\text { (lu/ml) }\end{array}$ & $\begin{array}{c}\text { Predicted } \\
\text { response } \\
\text { (lu/ml) }\end{array}$ \\
\hline 2 & 25.00 & 8.00 & 2.00 & 2.00 & 2.00 & 0.022 & 0.026 \\
\hline 3 & 35.00 & 6.00 & 2.00 & 1.00 & 2.00 & 0.018 & 0.019 \\
\hline 4 & 25.00 & 8.00 & 1.00 & 1.00 & 2.00 & 0.021 & 0.019 \\
\hline 5 & 35.00 & 6.00 & 2.00 & 2.00 & 2.00 & 0.023 & 0.023 \\
\hline 6 & 25.00 & 8.00 & 2.00 & 2.00 & 5.00 & 0.019 & 0.019 \\
\hline 7 & 30.00 & 7.00 & 1.50 & 1.50 & 3.50 & 0.037 & 0.042 \\
\hline 8 & 20.00 & 7.00 & 1.50 & 1.50 & 3.50 & 0.013 & 0.00856 \\
\hline 9 & 30.00 & 7.00 & 1.50 & 0.50 & 3.50 & 0.035 & 0.031 \\
\hline 10 & 25.00 & 6.00 & 1.00 & 1.00 & 2.00 & 0.016 & 0.019 \\
\hline 11 & 35.00 & 8.00 & 1.00 & 2.00 & 5.00 & 0.023 & 0.021 \\
\hline 12 & 25.00 & 6.00 & 2.00 & 1.00 & 5.00 & 0.023 & 0.022 \\
\hline 13 & 25.00 & 8.00 & 2.00 & 1.00 & 2.00 & 0.02 & 0.019 \\
\hline 14 & 30.00 & 7.00 & 2.50 & 1.50 & 3.50 & 0.038 & 0.033 \\
\hline 15 & 30.00 & 7.00 & 1.50 & 1.50 & 3.50 & 0.042 & 0.042 \\
\hline 16 & 30.00 & 7.00 & 1.50 & 1.50 & 6.50 & 0.033 & 0.035 \\
\hline 17 & 35.00 & 6.00 & 2.00 & 1.00 & 5.00 & 0.017 & 0.019 \\
\hline 18 & 30.00 & 7.00 & 1.50 & 1.50 & 0.50 & 0.051 & 0.044 \\
\hline
\end{tabular}




\begin{tabular}{|c|c|c|c|c|c|c|c|}
\hline Run & $\begin{array}{c}\text { Temperature } \\
\left({ }^{\circ} \mathrm{C}\right)\end{array}$ & $\mathrm{pH}$ & Glucose (g/l) & Peptone (g/l) & $\mathrm{NaCl}(\%)$ & $\begin{array}{l}\text { Experimental } \\
\text { response } \\
(\mathrm{lu} / \mathrm{ml})\end{array}$ & $\begin{array}{c}\text { Predicted } \\
\text { response } \\
\text { (lu/ml) }\end{array}$ \\
\hline 19 & 30.00 & 7.00 & 1.50 & 1.50 & 3.50 & 0.042 & 0.042 \\
\hline 20 & 30.00 & 7.00 & 1.50 & 1.50 & 3.50 & 0.043 & 0.042 \\
\hline 21 & 25.00 & 6.00 & 1.00 & 1.00 & 5.00 & 0.014 & 0.017 \\
\hline 22 & 25.00 & 8.00 & 1.00 & 2.00 & 5.00 & 0.019 & 0.019 \\
\hline 23 & 25.00 & 6.00 & 2.00 & 1.00 & 2.00 & 0.018 & 0.022 \\
\hline 24 & 30.00 & 7.00 & 1.50 & 1.50 & 3.50 & 0.04 & 0.042 \\
\hline 25 & 30.00 & 5.00 & 1.50 & 1.50 & 3.50 & 0.009 & 0.00506 \\
\hline 26 & 25.00 & 6.00 & 1.00 & 2.00 & 2.00 & 0.023 & 0.023 \\
\hline 27 & 25.00 & 8.00 & 1.00 & 1.00 & 5.00 & 0.018 & 0.018 \\
\hline 28 & 25.00 & 6.00 & 2.00 & 2.00 & 2.00 & 0.021 & 0.023 \\
\hline 29 & 35.00 & 6.00 & 1.00 & 1.00 & 2.00 & 0.017 & 0.017 \\
\hline 30 & 35.00 & 6.00 & 1.00 & 2.00 & 5.00 & 0.012 & 0.013 \\
\hline 31 & 35.00 & 8.00 & 1.00 & 1.00 & 2.00 & 0.015 & 0.019 \\
\hline 32 & 35.00 & 8.00 & 1.00 & 1.00 & 5.00 & 0.018 & 0.018 \\
\hline 33 & 25.00 & 6.00 & 2.00 & 2.00 & 5.00 & 0.017 & 0.016 \\
\hline 34 & 30.00 & 7.00 & 1.50 & 2.50 & 3.50 & 0.038 & 0.037 \\
\hline 35 & 25.00 & 6.00 & 1.00 & 2.00 & 5.00 & 0.014 & 0.013 \\
\hline 36 & 35.00 & 8.00 & 2.00 & 2.00 & 5.00 & 0.021 & 0.02 \\
\hline 37 & 35.00 & 8.00 & 2.00 & 2.00 & 2.00 & 0.027 & 0.027 \\
\hline 38 & 25.00 & 8.00 & 2.00 & 1.00 & 5.00 & 0.019 & 0.021 \\
\hline 39 & 35.00 & 6.00 & 1.00 & 1.00 & 5.00 & 0.017 & 0.014 \\
\hline 40 & 35.00 & 6.00 & 1.00 & 2.00 & 2.00 & 0.022 & 0.024 \\
\hline 41 & 30.00 & 9.00 & 1.50 & 1.50 & 3.50 & 0.012 & 0.011 \\
\hline 42 & 40.00 & 7.00 & 1.50 & 1.50 & 3.50 & 0.008 & 0.00736 \\
\hline 43 & 25.00 & 8.00 & 1.00 & 2.00 & 2.00 & 0.027 & 0.028 \\
\hline 44 & 35.00 & 8.00 & 1.00 & 2.00 & 2.00 & 0.031 & 0.031 \\
\hline 45 & 35.00 & 6.00 & 2.00 & 2.00 & 5.00 & 0.012 & 0.015 \\
\hline 46 & 35.00 & 8.00 & 2.00 & 1.00 & 2.00 & 0.015 & 0.018 \\
\hline 47 & 35.00 & 8.00 & 2.00 & 1.00 & 5.00 & 0.021 & 0.02 \\
\hline 48 & 30.00 & 7.00 & 1.50 & 1.50 & 3.50 & 0.042 & 0.042 \\
\hline 49 & 30.00 & 7.00 & 0.50 & 1.50 & 3.50 & 0.032 & 0.032 \\
\hline 50 & 30.00 & 7.00 & 1.50 & 1.50 & 3.50 & 0.045 & 0.042 \\
\hline
\end{tabular}



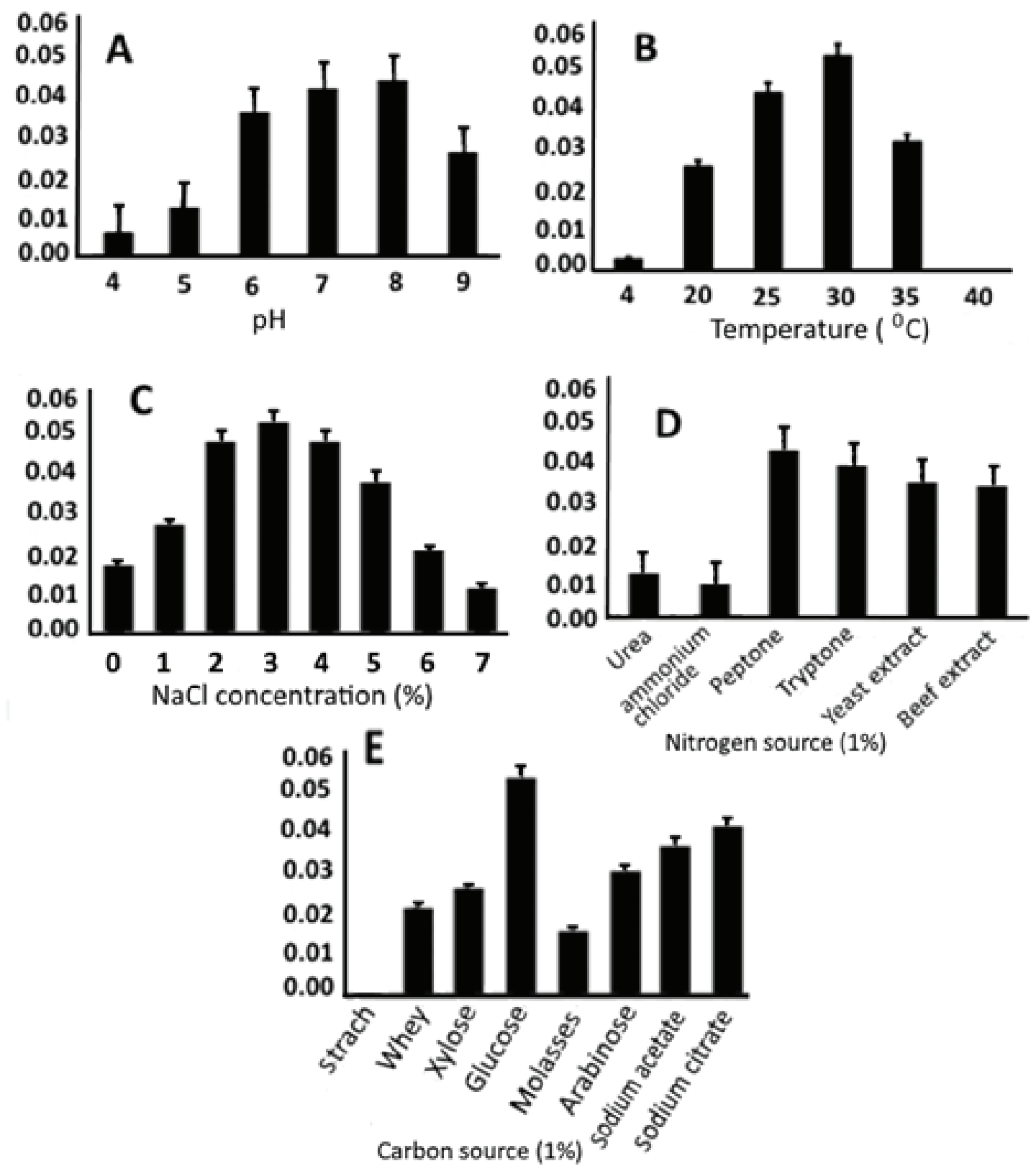

Figure 4: The results of OFAT experiments. Five variables affecting L-Asp production were studied at different levels, and the highest or most suitable levels were selected for RSM analysis. 


\subsection{Central composite design}

Based on CCD design, five factors were examined to optimize bacterial L-Asp production. The results obtained from 50 experiments suggested by the central composite design can be calculated by the following regression equation:

$$
\begin{aligned}
Y= & -0.70206+0.11475 * X 1+0.016 * X 3+-8.33333 E-006 * X 2 * X 4 \\
& -2.75000 E-003 * X 3 * X 4+1.57222 E-003 * X 4+9.16667 E-004 * X 4 * X 5 \\
& -8.45000 E-003 * X 12-3.38000 E-004 * X 22-7.80000 E-003 * X 32 \\
& -2.55556 E-004 * X 42
\end{aligned}
$$

Interaction of the variables was analyzed by annotated ANOVA to determine the effects of each variable alone and in combination. Statistical analyses and the estimated regression coefficients are presented in Table 3 . In this case, a quadratic model was found to be significant ( $p$-value $<0.05$ ), indicating that the process was constructed by a second order polynomial equation.

The regression analysis around the model indicated that $X 1, X 3, X 4, X 2 X 4, X 4 X 5, X 12$, $X 22, X 32$, and $X 42$ were significant $(P<0.05)$. The significance of the interactive terms (X2X4 and X4X5) indicates that the interactive effects of temperature on $\mathrm{NaCl}$ and $\mathrm{NaCl}$ on glucose may significantly affect L-Asp production. Additionally, the P-value of the lack of fit $(P>0.05)$ was insignificant, suggesting that the results predicted by model exhibit favorable fitness with the model.

The distance of adjusted R-squared compared to that of the predicted R-squared demonstrated the accuracy level of prediction based on the experimental results. Additionally, the Adeq precision value equal to 18.778 verified that the experiments were adjusted at a significant level (Ad-P $>4)$.

The three-dimensional plots represent the significant interactions of the independent variable pairs (Fig. 5). These plots could help to better understand the model and the interactive status between the independent factors. The optimum predicted responses are determined at highlighted points based on interactive forces on each pair of independent factors.

\section{Discussion}

Currently, the drugs used in the chemotherapy of leukemia are produced by Escherichia coli and Erwinia. Although L-Asp is produced by other sources such as certain fungi, 
TABLE 3: Analysis of variance (ANOVa) for L-Asp production by Rouxiella sp. AF1.

\begin{tabular}{l|c}
\hline Source & Terms \\
\hline Model & quadratic \\
$\mathrm{pH}\left(\mathrm{X}_{1}\right)$ & Linear \\
\hline Temperature $\left(\mathrm{X}_{2}\right)$ & Linear \\
\hline Peptone $\left(\mathrm{X}_{3}\right)$ & Linear \\
$\mathrm{NaCl}\left(\mathrm{X}_{4}\right)$ & Linear \\
\hline Glucose $\left(\mathrm{X}_{5}\right)$ & Linear \\
$\mathrm{X}_{1} \mathrm{X}_{2}$ & Interactive \\
$\mathrm{X}_{1} \mathrm{X}_{3}$ & Interactive \\
$\mathrm{X}_{1} \mathrm{X}_{4}$ & Interactive \\
$\mathrm{X}_{1} \mathrm{X}_{5}$ & Interactive \\
$\mathrm{X}_{2} \mathrm{X}_{3}$ & Interactive \\
\hline Parameter & \\
\hline Std. Dev. & \\
\hline Mean & \\
C.V. $\%$ & \\
PRESS &
\end{tabular}

\begin{tabular}{|c|}
\hline p-value \\
\hline$<0.0001^{*}$ \\
\hline $0.0075^{*}$ \\
\hline 0.5564 \\
\hline $0.0153^{*}$ \\
\hline $0.0001^{*}$ \\
\hline 0.3794 \\
\hline 0.4439 \\
\hline 0.6606 \\
\hline 0.2766 \\
\hline 0.9125 \\
\hline 0.2324 \\
\hline Value \\
\hline $3.188 \mathrm{E}-003$ \\
\hline 0.024 \\
\hline 13.09 \\
\hline $1.023 \mathrm{E}-003$ \\
\hline
\end{tabular}

\begin{tabular}{|c|r|}
\hline Source & Terms \\
\hline $\mathrm{X}_{2} \mathrm{X}_{4}$ & Interactive \\
\hline $\mathrm{X}_{2} \mathrm{X}_{5}$ & Interactive \\
\hline $\mathrm{X}_{3} \mathrm{X}_{4}$ & Interactive \\
$\mathrm{X}_{3} \mathrm{X}_{5}$ & Interactive \\
\hline $\mathrm{X}_{4} \mathrm{X}_{5}$ & Interactive \\
\hline $\mathrm{X}_{1}{ }^{2}$ & squared \\
\hline $\mathrm{X}_{2}{ }^{2}$ & Squared \\
$\mathrm{X}_{3}{ }^{2}$ & squared \\
\hline $\mathrm{X}_{4}{ }^{2}$ & Squared \\
\hline $\mathrm{X}_{5}{ }^{2}$ & squared \\
\hline Lack of Fit & - \\
\hline Parameter & \\
\hline R-Squared & \\
\hline Adj R-Squared & \\
\hline Pred R-Squared \\
Adeq Precision
\end{tabular}

\begin{tabular}{|c|}
\hline p-value \\
\hline $0.0439^{*}$ \\
\hline 0.5111 \\
\hline 0.1936 \\
0.2324 \\
\hline $0.0010^{*}$ \\
$<0.0001^{*}$ \\
\hline $0.0001^{*}$ \\
\hline $0.0003^{*}$ \\
\hline $0.0017^{*}$ \\
\hline 0.3161 \\
\hline 0.2698 \\
\hline Value \\
\hline 0.9490 \\
\hline 0.9139 \\
\hline 0.8231 \\
\hline 18.779 \\
\hline
\end{tabular}

Streptomyces, and various species of Pseudomonas and Serratia, it appears that the enzymes produced by the family Enterobacteriaceae exert greater therapeutic effects $[11,12]$. In this study, a bacterium belonging to Enterobacteriaceae (Rouxiella) isolated from farm soil exhibited a relatively strong L-Asp activity in the laboratory. Although number of species of Enterobacteriaceae other than Escherichia coli and Erwinia have been reported to possess enzymatic activity, no previous reports have been published detailing the L-Asp production of Rouxiella spp. Researchers have, however, reported similar findings from other Enterobacteriaceae. For example, Husain et al. (2016) isolated a bacterial strain from Enterobacteriaceae (Enterobacter cloacae) that possesses an inhibitory capability for human myeloid leukemia cells. From a structural and activity perspective, there are differences between our enzyme and the one isolated by Husian and colleagues. The main difference was in the enzymatic activity. The enzymes purified from Rouxiella possess an activity that is 2 -fold that of enzymes purified from E. cloaca $(0.022 \mathrm{IU} / \mathrm{ml})[2]$. The bacteria isolated in this research were from the family Enterobacteriaceae, and our study is the first to report the isolation of these bacteria from the soil. These bacteria have, however, been previously described by Fleche - Mateos and colleagues in 2013. They separated and characterized the bacterium from infant feeding bags that were contaminated with this bacterium [13]. The genus Rouxiella is comprised of three species, including $R$. chamberiensis, $R$. Badensis, and $R$. silvae. These three species exhibit identical phenotypic characteristics. Among these three species, only $R$. 

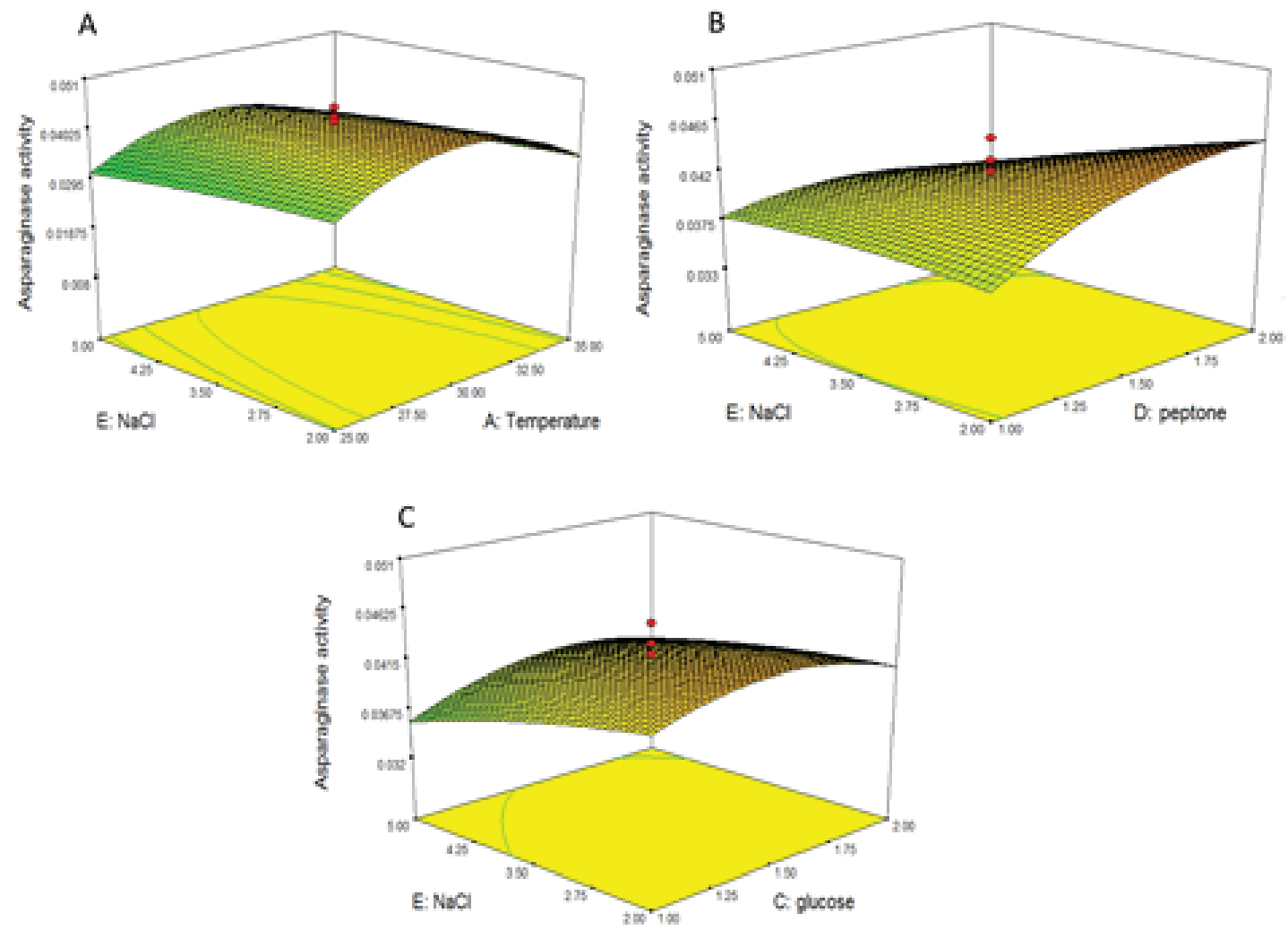

Figure 5: Three-dimensional surface plots. (a) Interactive effects between temperature and $\mathrm{NaCl}$ exhibited a polynomial curvature; (b) $\mathrm{NaCl}$ and peptone exhibit curvature and polynomial (c) $\mathrm{NaCl}$ and glucose possess significant polynomial curvature.

chamberiensis is able to produce pigment, and therefore, our bacteria is not $R$. badensis or $R$. silvae. Other differences between $R$. chamberiensis and other species include the ability to grow in $37^{\circ} \mathrm{C}$, to reduce nitrate, and to ferment raffinose. Unlike $R$. badensis that is able to ferment maltose, saccharose, and trehalose sugars, $R$. chamberiensis does not possess these capabilities. Finally, $R$. silvae is different from $R$. chamberiensis in that it is unable to grow at $37{ }^{\circ} \mathrm{C}$, to reduce nitrate, or to ferment trehalose, rhamnose, and maltose sugars. The GC content of its DNA is also different [14]. Therefore, the bacterial strain isolated in this research is identified as $R$. chamberiensis, and its asparaginase production activity is reported for the first time.

The major criteria for the use of L-Asp enzymes in medicines include their purity and higher specificity to Asn amino acid $[15,16]$. The aim of this study was to isolate a native bacterium producing L-Asp and to optimize the enzyme production. For this purpose, physiochemical conditions of the media and specific nutrients required to produce higher yields in short amounts of time required investigation. Nutrient substrates such as whey, molasses, oil recycled hydrocarbons, and agricultural wastes provide good targets. Therefore, achieving the optimum conditions for the production of L-Asp using 
inexpensive materials is favorable. In this study, the bacteria exhibited the ability to grow and produce enzymes in the presence of various carbon sources, which is a favorable characteristic for use in industrial processes.

When testing nitrogen sources, we observed that the presence of urea and ammonium carbonate resulted in decreased enzyme production; however, the use of peptone and urea or ammonium carbonate mixed together can reduce the cost of production. The best conditions for the production of metabolites occur at near-neutral $\mathrm{pH}$ levels, and the isolated bacterium exhibited the highest enzyme production within a range of $\mathrm{pH} 7$ to 8 throughout the 48 -hour period. These results were in agreement with the research performed by Renuka on Serratia marcescens bacterium [17]. The production conditions of the enzyme derived from the research by Sang Won are similar to those of this bacterium [18]. Another study by Mukherjee et al. in 2000 found that the best conditions for the production of asparaginase for Enterobacter aerogenes in the presence of $1 \%$ glucose are approximately $45 \mathrm{IU} / \mathrm{ml}$ [19]. Conversely, the effect of glucose as an enzyme inhibitor or activator is also discussed. In a study conducted by Kenari in 2011 on Escherichia coli, glucose inhibited enzyme production [20]; however, similar results were obtained regarding the effect of glucose on enzymatic activity in this study. In studying the effects of various carbon sources on growth and enzyme activity, glucose exerted the greatest effect on activity, and this was in agreement with the results obtained by Moorthy 2010 [21]. The production time for the enzyme depends upon the environmental conditions and the growth rate of the bacteria. In 2010, Moorthy found that optimum bacterial growth and enzyme production was achieved 24 hours after inoculation, while in the present study, the maximum production of enzymes occurred 48 hours after the initial inoculation, which was consistent with the results obtained by El-Bessoumy et al. [22]. Additionally, throughout the production process is crucial to monitor the interactions between environmental and nutritional factors in the context of microorganism growth and production yield. Given this, to optimize the production of a metabolite, the effects of the various environmental and growth factors on its production should first be determined. To determine the effective range of each factor in the enzyme production process, we used the one factor at a time method. For example, we adjusted a factor such as temperature to determine which temperature range would result in production of the highest amount of enzyme. The factors examined to generate the enzyme were time, temperature, source of carbon, nitrogen source, $\mathrm{pH}$, and salt content $(\mathrm{NaCl})$.

As described below, our next step was to design a model to achieve effective intervals where the reciprocal effects of these factors on the production of enzymes could be 
identified. Thus, it became possible to simulate the actual production conditions of the enzyme in industrial conditions. The results of this study indicated that the isolated bacteria possessed an activity level of $0.027 \mathrm{IU} / \mathrm{ml}$ before obtaining optimal conditions, and after obtaining optimal conditions this increased to $0.02 \mathrm{IU} / \mathrm{ml}$, which represents a 2 -fold increase. In contrast, the activity level in the dialysate solution was $0.32 \mathrm{IU} / \mathrm{ml}$, indicating a 6-fold increase in enzyme activity. Although extensive studies have been conducted on the isolation and purification of the L-Asp enzyme and its anticancer properties, no information is available concerning the production of this enzyme by the Rouxiella genus. The results of relative purification and molecular weight evaluation of the enzyme, both of which were performed using the Sephadex-DEAE column and SDSPAGE, indicated that the molecular weight of the isolated enzyme was approximately $115 \mathrm{KDa}$. A large number of studies examining the molecular mass of the asparaginase enzyme have been performed, and in most of these studies, a high molecular weight (from KDa 34 to KDa 200) has been obtained for this enzyme [23-26]. In this study, the results in some cases were similar to those of others, and in some cases, they contradicted the previous findings. The reason for these differences may be due to errors caused by measuring the activity of the enzyme, and it is also possible that these differences are due to artifact. To ensure that our results were reliable, we tested the ability of the enzyme in a situation where our main goal is to be met. Given this, the most important test is the study of the anticancer activity of this enzyme in the context of cell lines and laboratory animals. The results obtained from these comparisons suggest that the Rouxiella AF1 bacteria are distinct in terms of their metabolic characteristics and isolation sources compared to other bacteria, especially Enterobacteriaceae, and certain characteristics of the asparaginase enzyme are also clear. For example, the enzyme obtained in this study is less active than the other asparaginases obtained by previous researchers. According to previous reports, high enzyme activity does not indicate the suitability of the enzyme for drug use, and instead, the ability to maintain the activity of L-Asp under physiological conditions within the blood, specifically $\mathrm{pH}$ and osmolarity, plays a very important role in enzyme suitability for therapeutic use $[27,28]$.

\section{Conclusions}

L-Asp produced by Rouxiella sp. AF1 exhibited reliable antitumor activity. In the optimization of L-Asp production, the combination of OFAT with central composite design 
provided an efficient approach to determine the optimal conditions for bacterial fermentation. Extraction and purification of L-Asp from the culture medium by a combination of salting-out and precipitation by ammonium sulfate yielded low enzyme content; however, the amount of non-specific proteins, particularly other enzymes, decreased significantly. Further purification steps provided satisfactory yields. This study demonstrated that the use of native bacteria to discover new metabolites, especially L-Asp, may enhance our chances of discovering novel sources of therapeutic drugs when their source has been isolated from unknown environments possessing unique ecological properties.

\section{Acknowledgments}

The study was financially supported by Islamic Azad University, Khorramabad branch.

\section{Conflict of Interest}

The authors declare no conflict of interest.

\section{References}

[1] Izadpanah QF, Homaei A, Fernandes P, Javadpour S. Marine microbial LAsparaginase: Biochemistry, molecular approaches and applications in tumor therapy and in food industry. Microbiol Res. 2018;208:99-112.

[2] Husain I, Sharma A, Kumar S, Malik F. Purification and characterization of glutaminase free asparaginase from Enterobacter cloacae: in-vitro evaluation of cytotoxic potential against human myeloid leukemia HL-60 cells. PloS One. 2016;11(2):e0148877.

[3] Egler RA, Ahuja SP, Matloub Y. L-Asparaginase in the treatment of patients with acute lymphoblastic leukemia. J Pharmacol Pharmacother. 2016;7(2):62.

[4] War Nongkhlaw FM, Joshi SR. L-Asparaginase and antioxidant activity of endophytic bacteria associated with ethnomedicinal plants. Indian Journal of Biotechnology. 2015;14(1):59-64.

[5] Ali U, Naveed M, Ullah A, Ali K, Shah SA, Fahad S, Mumtaz AS. L-asparaginase as a critical component to combat Acute Lymphoblastic Leukaemia (ALL): A novel approach to target alL. European Journal of Pharmacology. 2016; 771: 199-210.

[6] Ghorbanmovahed M, Ebrahimipour G, Akhtari J, Marzban A. Production of antileukemia L-Asparaginase by a strain of Staphylococcus Isolated from Agricultural 
Soil. Journal of Mazandaran University of Medical Sciences. 2016;25(132):1-12.

[7] Holt JG, Krieg NR, Sneath PHA, Staley JT, Williams ST. Bergey's Manual of Determinative Bacteriology. 9th ed. Baltimore: Williams \& Wilkins; 1994.

[8] Teymouri M, Karkhane M, Marzban M, Marzban A. Designing a Response Surface Model for Removing Phosphate and Organic Compound from Wastewater by Pseudomonas Strain MT1. Proc Natl Acad Sci India Sect B Biol Sci. 2017;87(4):1167-76.

[9] Teymouri M, Karkhane M, Gilavand F, Akhtari J, Marzban A. Extracellular lipase purification from a marine Planomicrobium sp. MR23K and productivity optimization in a pilot-scale submerged bioreactor. Proc Natl Acad Sci India Sect B Biol Sci. 2018;88(2):739-46.

[10] Ramya LN, Doble M, Rekha VPB, Pulicherla KK. L-Asparaginase as potent antileukemic agent and its significance of having reduced glutaminase side activity for better treatment of acute lymphoblastic leukaemia. Appl Biochem Biotechnol. 2012;167(8):2144-59.

[11] El-Sabbagh SM, El-Batanony NH, Salem TA. L-Asparaginase produced by Streptomyces strain isolated from Egyptian soil: Purification, characterization and evaluation of its anti-tumor. Afr J Microbiol Res. 2013;7:5677-86.

[12] El-Bessoumy AA, Sarhan M, Mansour J. Production, isolation, and purification of LAsparaginase from Pseudomonas aeruginosa 50071 using solid-state fermentation. Journal of Biochemistry and Molecular Biology. 2004;37(4):387-93.

[13] Le Flèche-Matéos A, Kügler JH, Hansen SH, Syldatk C, Hausmann R, Lomprez F, et al. Rouxiella badensis sp. nov. and Rouxiella silvae sp. nov. isolated from peat bog soil and emendation description of the genus Rouxiella. Int J Syst Evol Microbiol. 2017;67(5):1255-9.

[14] Le Flèche-Matéos A, Levast M, Lomprez F, Arnoux $\mathrm{Y}$, Andonian C, Perraud $\mathrm{M}$, et al. Rouxiella chamberiensis gen. nov., sp. nov., a member of the family Enterobacteriaceae isolated from parenteral nutrition bags. Int J Syst Evol Microbiol. 2015;65(6):1812-8.

[15] Sharma A, Husain I. Optimization of medium components for extracellular glutaminase free asparaginase from Enterobacter cloacae. Int J Curr Microbiol App Sci. 2015;4(1):296-309.

[16] Chan WK, Lorenzi PL, Anishkin A, Purwaha P, Rogers DM, Sukharev S, et al. The glutaminase activity of L-Asparaginase is not required for anticancer activity against ASNS-negative cells. Blood. 2014:blood-2013-10-535112. 
[17] Renuka DK, Santhi R, Sheeba D, Sangeetha R, Joshua S, Prabisha T, et al. Isolation, production and partial purification of L-Asparaginase from Serratia marcescens. Int J Recent Sci Res. 2012;3(1):1008-12.

[18] Han S, Jung J, Park W. Biochemical characterization of L-Asparaginase in $\mathrm{NaCl}$ tolerant staphylococcus sp. OJ82 isolated from fermented seafood. J Microbiol Biotechnol. 2014;24(8):1096-104.

[19] Mukherjee J, Majumdar S, Scheper T. Studies on nutritional and oxygen requirements for production of L-Asparaginase by Enterobacter aerogenes. Appl Microbiol Biotechnol. 2000;53(2):180-4.

[20] Kenari SLD, Alemzadeh I, Maghsodi V. Production of L-Asparaginase from Escherichia coli ATCC 11303: Optimization by response surface methodology. Food and Bioproducts Processing. 2011;89(4):315-21.

[21] Moorthy V, Ramalingam A, Sumantha A, Shankaranaya RT. Production, purification and characterisation of extracellular L-Asparaginase from a soil isolate of Bacillus sp. African Journal of Microbiology Research. 2010;4(18):1862-7.

[22] El-Bessoumy AA, Sarhan M, Mansour J. Production, isolation, and purification of LAsparaginase from Pseudomonas aeruginosa 50071 using solid-state fermentation. BMB Reports. 2004;37(4):387-93.

[23] Singh Y, Gundampati RK, Jagannadham MV, Srivastava S. Extracellular LAsparaginase from a protease-deficient Bacillus aryabhattai ITBHU02: purification, biochemical characterization, and evaluation of antineoplastic activity in vitro. Appl Biochem Biotechnol. 2013;171(7):1759-74.

[24] Kumar S, Venkata Dasu V, Pakshirajan K. Purification and characterization of glutaminase-free L-Asparaginase from Pectobacterium carotovorum MTCC 1428. Bioresour Technol. 2011;102(2):2077-82.

[25] Manna S, Sinha A, Sadhukhan R, Chakrabarty S. Purification, characterization and antitumor activity of L-Asparaginase isolated from Pseudomonas stutzeri MB-405. Curr Microbiol. 1995;30(5):291-8.

[26] Pritsa AA, Kyriakidis DA. L-Asparaginase of Thermus thermophilus: Purification, properties and identificaation of essential amino acids for its catalytic activity. Mol Cell Biochem. 2001;216(1-2):93-101.

[27] Srikhanta YN, Atack JM, Beacham IR, Jennings MP. Distinct physiological roles for the two L-Asparaginase isozymes of Escherichia coli. Biochem Biophys Res Commun. 2013;436(3):362-5.

[28] Mahajan RV, Kumar V, Rajendran V, Saran S, Ghosh PC, Saxena RK. Purification and characterization of a novel and robust L-Asparaginase having low-glutaminase 
activity from Bacillus licheniformis: in vitro evaluation of anti-cancerous properties. PLoS One. 2014;9(6):e99037. 